day. Blistering was sometimes of service, but ammonia was of little value; while the cold douche, applications of ice, etc., he thought did more harm than good. The great reliance must be on specific treatment, and the best method of employing it was in the form of mercurial inunctions. Ihere was perhaps nothing so good for this purpose as the old time ointment; though the oleate of mercury, made with the yellow oxide, was excellent too. I anolin could also be used with good results as a vehicle for the mercury. For hypodermic use the bichloride was the best preparation, and care should be taken to make the injections deep in the gluteal muscles, so as to avoid as far as possible the risk of abscesses.

In treating of syphilitic hemiplegia he referred to a variety of different types, scarcely any two cases being precisely alike; but remarked that they all had certain points in common. In the first place, syphilitic hemiplegia almost invariably occurred in males ( 95 per cent. of all cases being males) ; secondly, it occurred in the young (between the ages of 18 and 40); and third, it was characterized by the peculiar behavior of the deep reflex phenomena. The diagnosis of this affection by the test of treatment was often fallacious, for many cases were not materially benefited by specific treatment. There was, however, one truly pathognomonic sign, viz. : an excessive exaggeration of the deep tendon reflexes, both of the upper and lower extremities; and it is upon this symptom that Dr. Althaus depends in mak. ing the diagnosis of syphilitic hemiplegia. It can only be depended upon, of course, in cases in which the reflexes on one side are normal. The treatment, he said, is not always satisfactory, and therefore in such instances the prognosis is not good; and some cases unfortunately terminate in general paresis. It is the secondary consequences of the syphilitic process which often prove unamenable to treatment; for the removal of a syphilitic gumma will not restore the nerve cells and fibres which have already been destroyed. 'The lesson to be derived from these cases, therefore, is, that active treatment must be commenced as soon as there is the slightest evidence of cerebral trouble. The secondary ordinary lesions which result from syphilitic lesions of the brain are not, unfortunately, affected by anti-syphilitic treatment.

In discussing this division of the paper Dr. Robert W. Taylor, the well-known syphilographer, spoke of the labors of Drs. Van Buren and Keyes, of this city, in connection with syphilitic hemiplegia, and called attention to the fact that in a paper read here a number of years ago, which embodied these researches, and which had now been incorporated in several text-books, Dr. Keyes had described all the prominent symptoms to which Dr. Althaus had referred this evening.

As regards the treatment of cerebral syphilis, Dr. Gray remarked that he was sumewhat surprised at the views expressed by Dr. Althaus. He depended, it seemed, entirely on mercurials, and had little or nothing to say in regard to iodide of potassium. For his part, he had some time since given up the use of mercury altogether in these cases, as he had never seen any beneficial results from it. He had had indisputable evidence in his experience of the superior value of the iodide, and he believed that this was the experience also of the great majority of neurologists in this country.

Dr. Putzel, on the other hand, stated that he agreed entirely with the author of the paper in regard to the marked efficiency of mercury. It was now about six years since he had become convinced that syphilis did not yield, or at least very slowly, to jodide of potassium. Formerly he employed the bichloride of mercury: but more recently he had found much better results from the use of inunction. It was his practice to employ this antil the teeth began to be touched, and then to discontinue it. In connection with this, small doses of iodide of potassium sometimes seemed of service.

On the following evening I)r. Althaus read before the Neurological Section of the Academy of Medicine a paper on "The Pathology and Treatment of Paraplegia resulting from Potts' Disease," the object of which was to advocate the use of the actual calitery, and this at as early a period as possible; since if the sensibility was already affected, it would be of no service. It was the opinion of most of those present, however, that while in occasional instances the actual cautery might be beneficial, therre were other methods of treatment at our command which were, as a general rule, much preferable and much more efficient. P. B. $P$.

\section{MR. TAIT ON "OTOMIES."}

TO THE EDITOR OF THE JOURNAL:

Dear Sir:-Having been much interested in the discussion on the letter of Mr. Iawson Tait to Dr. Nelson, read before the Chicago Gynæcological Society on May 28, I hope you will permit me to add a few words to what was said on that occasion.

1 think that $\mathrm{Mr}$. Tait is wrong in "protesting against those stupid Greek words ending in otomy," for by so doing he ignores a necessity, long recognized by scientists, of borrowing, from some classical language, their technical terms. If they were all of one nation and spoke the same tongue, there would be no such necessity; but in order that the different nations might profit by each other's work, it is necessary that they adopt conventional terms that would be understood everywhere.

'The term "abdominal section," preferred by $\mathrm{Mr}$. Tait, would do very well for all of us English-speaking people, but it would convey to a German no more meaning than his "Bauchschnitt" does to us. Without these conventional terms the work of any one nation would be a dead letter to all others, and and each would be obliged to prosecute their scientific studies independently; so that to communicate and compare their work, these conventional terms become a necessity.

The Latin and Greek languages, which occupy so important a position in the curricula of the colleges, are understood by educated men the world over, and have therefore been adopted as the medium of intercommunication. The Greek being the more fertile, 
has supplied us with most of our technical terms, without which the study of the sciences would have dragged heavily, and could hardly by this time have reached their present status.

Though Mr. Tait is evidently a better surgeon than linguist, it is somewhat surprising that the term "oncotomy" should be new to him. He must have met with it, and it is strange that, by its very ugliness, it was not impressed on his mind. It is a very old word, being contained in Dunglison's dictionary at least forty years ago. Professor Fenger was evidently right in clesignating mere opening of an abscess or tumor by this name, its derivation being from the Greek $o y \varkappa \infty$, a tumor or abscess.

Mr. Lawson 'Tait objects to the word "laparotomy" "because the signification of its derizatives (italics mine) in the use of the people who spoke the language is such that it could not by any human ingenuity be applied to any modern surgical proceeding;" but he must be reminded that it is ave who make the "derivatives" from the roots supplied by "the people who spoke the language" to describe "our modern surgical proceedings." A greater ob. jection to this term, in my opinion, is, that it might justify an inference that the operation (abdominal section) was limited to the lumbar region, it being derived from $\lambda \alpha \pi \alpha \delta \alpha$, the loins. On this account "gastrotomy," which seems to be the favorite term with the French, is much less objectionable. But perhaps the term least liable to objection is the one proposed by Dr. Fenger, viz.., "peritonotomy," notwithstanding it has the termination so abhorent to the distinguished English surgeon.

We all must acknowledge, however, that Mr. Lawson 'Tait's wonderful success in this particular branch of surgery, which has justly given him a world-wide reputation, should entitle him to the privilege of selecting its name, whether from the English or any language he prefers.

Norfolk, Va., August 20, 1886.

TOXIC URINE AND SURGICAL OPERATIONS. TO THE EDrTOR OF THE JOURNAI:

$\dot{D}_{c a r}$ Sir:-I am pleased with the editorial, "Toxic Urine and Surgical Operations," in The Journat, of October 2d, and hope that $\mathrm{Mr}$. Reginald Harrison is entitled to all the attention your article bestows upon him, but an American, Prof. Hal C. Wyman, of Detroit, published, some years ago, ideas so very similar to those you attribute to Mr. Harrison in his article in the Liverpool Medico.Chirurgical Journal, that I cannot refrain from using this occasion to say that Dr. Wyman not only described all the toxic effects mentioned by Mr. Harrison, but devised an operation for relief of hypertrophied prostate, the main feature of which was that no urine could come in contact with the wound to poison it.

The principles involved in your editorial are very important. I feel that it is only right that our countrymen should have full credit for any good work they have done. Under the title of "Tenotomy of the Levator Prostatæe," Prof. Wyman published an article in the Medical Age, of January, s 883, in which he advised special surgical measures to avoid the toxic effects of urine. At the time the article was often quoted by other medical journals, and must be still fresh in the minds of many American surgeons.

Bluefield, Mich., Oct. 5, 1886.

DaYTon PARKer, M.D.

\section{NECROLOGY.}

\section{JAMES IRVIN KELLER, M.D.}

Died at his home, Hot Springs, Arkansas, on September 29, of typhoid fever, DR. JAMk.s lRviN Ketrore, aged 31 years, 5 months and 18 days. By request we clip the following from the Mimphis Appeal:

'The Appeal has already announced the deatin of this brilliant young man; but at the request of those nearly allied with the deceased we give additional particulars as to his death and our further estimate of his character. The deceased was young, handsome and accomplished. God gave him a massive intellect, and beneath his ample brow lay a capacious brain comprehensive in grasp and which did much mighty thinking. His language was ornate, his style terse and beautiful, and in conversation he was voluble and interesting. He was one of those extraurdinary creations who leap into manhood without the probation of youth, for be was eminent in his profession by the time he reached his majority. Nowoncer his father, Dr. James M. Keller, and his mother, Mrs. Sallie Phillips Keller, made him the idol of their lives, and worshipped him as a bright particular star whose radiance was destined to grow in splendor long after they had crumbled into dust. But "whom the Gods love die young," and the sun of Dr. Irvin Keller went down ere it reached its noon, but is sunk amid the prophetic splendors of an eternal dawn. Never was there a death seen more pathetic than his. No man ever had greater inducements to live; but young as he was, he was a philospher, and he met the fate which his knowledge as a physician told him was in. exorable with the courage of a hero. He summoned the family and his friends to his bedside, and said to Dr. Rector: "I am about ta pay that debt which we all must pay sooner or later, but I shall do so like a man;" and death in all his triumphs never mocked at a scene so pathetic and heart-rending. Farewell, noble Irvin. We knew you in infancy, in childhood, in boyhood and manhood. Your life was a poem, a perfect star, and the loyal hearts that loved you are bleeding, but they will ever be harps tuned to the sweet melody of remembrance. You have left unfinished the beautiful pyramid you were building to your fate, but like the lightning which leaves more picturesque the shattered shaft, death has not destroyed the symmetry and brightness of your life. Heaven gave you everything but time to accomplish a great mission You "flashed, the meteor of an hour," and the darkness your death has created tells of the brilliance of the light that has forever gone out. While dropping tears over your grave, the sympathies of your loving friends will be lavished upon 